\title{
TO THE ISSUE OF THE PROBABLE ROLE OF PLANT PROTECTION CHEMICALS IN THE FORMATION OF POPULATION ONCOLOGICAL INCIDENCE
}

Chernychenko I.O., Lytvychenko O.M., Babii V.F., Fedorenko Z.P., Tsymbaliuk S.M., Balenko N.V., Kondratenko O.Ye., Hlavachek D.O.

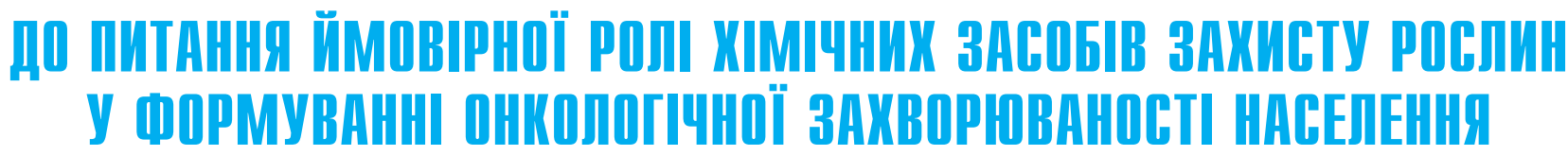

\author{
1ЧЕРНИЧЕНКО І.О., \\ 1 ЛИТВИЧЕНКО О.М., \\ 1БАБІЙ В.Ф., \\ ЗФЕДОРЕНКО З.П., \\ 2ЦИМБАЛЮК С.М., \\ 1БАЛЕНКО Н.В., \\ 1 КОНДРАТЕНКО О.Є., \\ 1ГЛАВАЧЕК Д.О.
}

1 ДУ «Інститут громадського здоров'я ім. О.М. Марзєєва НАМН України», М. Київ, Україна 2Київський міський ендокринологічний центр МОЗ України, м. Київ, Україна зНаціональний інститут раку МОЗ України, м. Київ, Україна

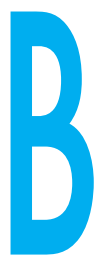

останнє десятиріччя фахівці у галузі охорони навколишнього середовища та збереження громадського здоров'я особливу увагу приділяють хімічним факторам пошкодження ендокринної системи, які позначаються як хімічні руйнівники ендокринної системи (XРЕC).

Нині вже ідентифіковано понад 1000 різних хімічних сполук з таким характером дії.

Пріоритетними з них є

$\square$ хімічні речовини промислових викидів, особливо продукти спалювання органічної сировини - поліциклічні ароматичні вуглеводні, важкі метали, біфеніли, діоксини тощо;

$\square$ хімічні засоби захисту рослин (ХЗЗР) - пестициди (фунгіциди, гербіциди, інсектициди тощо);

口 хімічні сполуки антропогенного походження, які $\epsilon$ складовими різноманітних косметичних засобів, предметів побутової хімії та мийних засобів, пластмасових виробів;

$\square$ фармацевтичні та терапевтичні засоби тощо.

Важливим аспектом впливу XPEC $є$ той факт, що незважаючи на різні механізми дії за їх сумісного впливу на людину зростає ризик шкідливих ефектів навіть на рівнях, які за умов ізольованого
ДО ПИТАННЯ ЙМОВІРНОÏ РОЛІ ХІМІЧНИХ ЗАСОБІВ ЗАХИСТУ РОСЛИН

У ФОРМУВАННІ ОНКОЛОГІЧНОЇ

ЗАХВОРЮВАНОСТІ НАСЕЛЕННЯ

1 Черниченко І.О., 1Литвиченко О.М.,

1 Бабій В.Ф., ЗФедоренко З.П.,

2Цимбалюк С.М., 1 Баленко Н.В.,

1 Кондратенко О.Є., 1 Главачек Д.О.

1 ДУ «/нститут громадського здоров'я

ім. О.М. Марзєєва НАМН України»,

м. Київ, Україна

${ }^{2}$ Київський міський ендокринологічний центр

м0З України, м. Київ, Україна

знаціональний інститут раку МОЗ України, м. Київ, Україна

Мета: оцінити ймовірну роль пестицидів як узагальнюючих продуктів хімічних засобів захисту рослин у формуванні гормонозалежної онкологічної захворюваності населення. Матеріали та методи. У роботі проаналізовано територіальні особливості використання хімічних засобів захисту рослин і дані захворюваності населення на рак ендокринних органів (рак молочної і щитоподібної залоз у жінок та чоловіків, рак простати у чоловіків, рак яєчників і тіла матки у жінок, розрахованих за українським стандартом) за матеріа- лами Національного канцер-реєстру України Результати. Виявлено територіальні залежності між валовими показниками використовуваних хімічних засобів захисту, темпами їх збільшення у сільському господарстві $i$ показниками захворюваності населення на рак ендокринних органів. Показано, що найбільш інтенсивно ростуть показники в областях з переважно сільськогосподарським напрямом виробництва. Проведений лінійнорегресійний аналіз підтвердив наявність прямого сильного кореляційного зв'язку між обсягами застосування у господарстві пестицидів і захворюваністю на прикладі раку яєчників у жінок $(r=0,89 ; p>0,01)$ і раку простати у чоловіків ( $r=0,87 ; p>0,01)$.

Висновок: хоча результати аналітичного розгляду проблеми і дані лінійно-регресійного аналізу вказують на можливу роль пестицидів в індукуванні раку ендокринних органів, необхідно продовжити дослідження у цій області. Важливо у подальшому розглянути проблему за класами і групами пестицидів з можливістю підійти до визначення механізмів дії.

Ключові слова: хімічні засоби захисту рослин,онкологічна захворюваність населення, територіальні особливості.

() Черниченко І.О., Литвиченко О.М., Бабій В.Ф., Федоренко З.П.,

Цимбалюк С.М., Баленко Н.В., Кондратенко О.Є., Главачек Д.О.

СTATTЯ, 2020. 


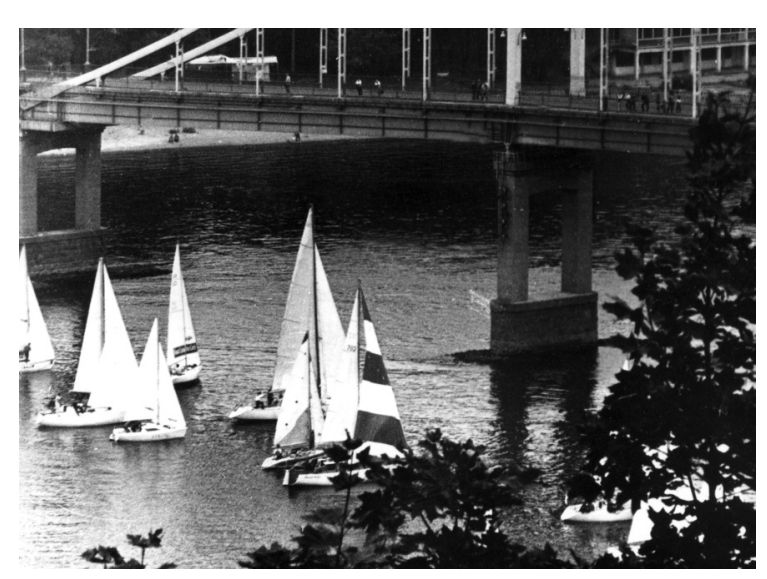

надходження до організму є недіючими [1, 2].

При цьому широкий спектр засобів різноманітного призначення та характер їх поширення серед населення нівелює існуючу до останнього часу різницю особливостей умов життєдіяльності міського та сільського населення.

Отже, якщо винести за дужки речовини чисто антропогенного походження, які впливають на населення 3 промисловими викидами, усі інші чинники за повнотою свого поширення останнім часом є характерними у використанні і сільського, і міського населення.

Зважаючи на необхідність визначення експозиційної дози речовини для оцінки небезпеки її для здоров'я, важливим $€$ таке. На жаль, моніторування вмісту у довкіллі хімічних речовин антропогенного походження на державному та міському рівнях здійснюється лише для обмеженого їх числа, тоді як в оточуючому людину середовищі (атмосферне повітря населених місць, повітря побутових приміщень, зони застосування XРЕС тощо) вміст препаратів та окремих складових косметичних та побутових виробів і засобів захисту рослин залишаються недослідженими і неконтрольованими.

Для вирішення цього питання метою роботи стала оцінка ймовірної ролі пестицидів як узагальнених продуктів хімічних засобів захисту рослин у формуванні гормонозалежної онкологічної захворюваності.

Матеріали та методи дослідження. На основі літературних даних та матеріалів обласних статистичних звітів було проаналізовано обсяги використаних ХЗЗР в Україні за 2000-2016 роки.

Зонами спостережень були території країни, поділені за характером промислового розвитку на такі області:

п переважно високоіндустріалізовані,

п переважно сільськогос- подарської діяльності,

в зі змішаним профілем господарювання,

口 підвищеного радіаційного контролю,

口 ендемічні за вмістом йоду.

Поділ територій здійснювався за матеріалами статистичних довідників щодо економічного розвитку України на обласному рівні.

За основу вирішення питання щодо поширення онкологічної захворюваності населення на рак ендокринних органів було взято матеріали Національного канцер-реєстру України за 2008-2018 роки. Аналізу підлягали показники захворюваності населення на рак щитоподібної, передміхурової та молочної залоз, а також яєчників та тіла матки, розраховані за українським стандартом.

Обробку інформації проводили 3 використанням загальноприйнятих у медикобіологічних дослідженнях статистичних методів та tкритерію Ст'юдента [3].

Результати та їх обговорення. Виконуючи дану роботу, ми розуміли, що достовірність результатів залежатиме від чіткого визначення спектра діючих речовин. Проте, на жаль, нині, як вже відзначалося, моніторинг використання ХЗЗР, що впливають на ендокринні органи, як і на організм загалом не ведеться. Для вирішення поставленої мети ми виходили 3 можливості опосередкованого визначення ймовірної ролі ХЗЗР у формуванні онкологічної патології за показниками валових обсягів їх використання у сільськогосподарсь- кій діяльності. До того ж валові показники охоплюють також обсяги, що останнім часом безконтрольно усе більше використовуються населенням на присадибних і дачних ділянках.

Загалом аналіз динаміки асортименту ХЗЗР, дозволених до застосування на теренах України, свідчить про динамічну тенденцію до їх збільшення, особливо в останні кілька десятиріч. 3окрема, 2001 року було зареєстровано 350 препаратів, тоді як на 2016 рік їх збільшилося до 10747 [4]. 3 них на 2019 рік асортимент ХЗЗР, що використовувалися у сільському господарстві, нараховував понад 2000 препаратів на основі сотень діючих речовин $[5,6]$. Аналіз пріоритетних препаратів, що використовуються в Україні, наведено у першому довіднику пестицидів [6], який узагальнює та систематизує результати багаторічних фундаментальних і прикладних досліджень пестицидів і агрохімікатів.

у структурі асортименту ХЗЗР, дозволених до застосування в Україні, найбільша частка припадає на гербіциди - у середньому близько 50-55\%. Друге місце за кількістю препаратів належить фунгіцидам - 20-25\%. Інсектициди у структурі асортименту пестицидів становлять менше 15\%, проте за своєю токсичністю та небезпечністю у разі надходження до організму людини вони $€$ найбільш небезпечними [1]. Темпи використання ХЗЗР невпинно зростають, про що свідчать дані таблиці 1 [1, 4, 7]. Від 2001 по 2016 рік їхні 
валові обсяги збільшилися майже втричі. Причому це є характерним для усієї сільськогосподарської території країни, хоча за валовими обсягами таки найбільше використовуються пестициди на території промислово розвинених та сільськогосподарських областей. I навпаки, показники використання ХЗЗР на територіях, ендемічних за вмістом йоду, та областей підвищеного радіа-

Темпи зростання обсягів використання хімічних засобів захисту рослин та їхні кількісні показники залежно від характеру промислового розвитку території

\begin{tabular}{|c|c|c|}
\hline \multirow{4}{*}{ Території } & \multicolumn{2}{|c|}{ Час спостережень } \\
\hline & 2001 рік & 2016 рік \\
\hline & \multicolumn{2}{|c|}{$\begin{array}{l}\text { Середньообласні обсяги } \\
\text { використання ХЗЗР, тонн }\end{array}$} \\
\hline & $\begin{array}{l}\text { Min-Max } \\
\text { Mcep } \pm m\end{array}$ & $\begin{array}{l}\text { Min-Max } \\
\text { Mcep } \pm m\end{array}$ \\
\hline $\begin{array}{l}\text { Області переважно } \\
\text { промислового розвитку }\end{array}$ & $\begin{array}{l}574.5-588.0 \\
580.3 \pm 7.6\end{array}$ & $\begin{array}{l}1425.2-2254.3 \\
1634.0 \pm 367.4\end{array}$ \\
\hline $\begin{array}{l}\text { Області переважно сільсько- } \\
\text { господарської діяльності }\end{array}$ & $\begin{array}{l}279.1-1242.4 \\
696.3 \pm 514.2\end{array}$ & $\begin{array}{c}815.9-2875.2 \\
1713.2 \pm 787.1\end{array}$ \\
\hline $\begin{array}{l}\text { Області змішаного типу } \\
\text { господарювання }\end{array}$ & $\begin{array}{l}298.0-984.8 \\
606.1 \pm 264.3\end{array}$ & $\begin{array}{c}736.3-2131.6 \\
1399.2 \pm 694.1\end{array}$ \\
\hline $\begin{array}{l}\text { Області підвищеного } \\
\text { радіаційного контролю }\end{array}$ & $\begin{array}{c}193.6-603.0 \\
288.3 \pm 174.8\end{array}$ & $\begin{array}{l}570.9-1212.2 \\
910.5 \pm 317.4\end{array}$ \\
\hline $\begin{array}{l}\text { Області, ендемічні } \\
\text { за вмістом йоду }\end{array}$ & $\begin{array}{c}33.8-138.8 \\
102.8 \pm 48.2\end{array}$ & $\begin{array}{c}210.3-633.7 \\
394.3 \pm 186.3\end{array}$ \\
\hline
\end{tabular}

ційного контролю є суттєво нижчими.

Цікаво, що паралельно побудовані ряди онкологічної захворюваності ендокринних органів є майже тотожними 3 даними щодо використання обсягів ХЗЗР (табл. 2).

Це особливо чітко проявляється за показниками раку щитоподібної, молочної та передміхурової залоз, темпи зростання яких відповідають обсягам використан-

Таблиця 1
Отже, широкий спектр речовин, що використовуються як ХЗЗР у сільському господарстві і у залишкових кількостях 3 харчовими продуктами, впливають на населення, з одного боку, і наявність інших можливих супутніх факторів, що призводять до розвитку раку у людей, з іншого, унеможливлюють встановлення прямого зв'язку між використовуваними у даній місцевості пестицидами і захворюваністю на рак ендокринних органів. Хоча слід зазначити, що нині існує низка публікацій, в яких епідеміологічно встановлено зв'язок між експозицією деяких конкретних пестицидів і захворюваністю на окремі конкретні форми раку, у тому числі гормонозалежних органів [1, 8-15].

Таблиця 2

\section{Середньообласні показники захворюваності населення України на рак ендокринних органів (на 100 тис. нас.) залежно від характеру промислового та природного стану}

\begin{tabular}{|c|c|c|c|c|c|c|c|c|c|c|c|c|c|c|}
\hline \multirow{3}{*}{ Території } & \multicolumn{4}{|c|}{$\begin{array}{c}\text { Рак } \\
\text { щитоподібної залози }\end{array}$} & \multicolumn{4}{|c|}{$\begin{array}{c}\text { Рак } \\
\text { молочної залози }\end{array}$} & \multirow{2}{*}{\multicolumn{2}{|c|}{ 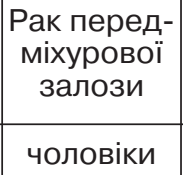 }} & \multirow{2}{*}{\multicolumn{2}{|c|}{\begin{tabular}{|c} 
Рак \\
яєчників \\
жінки
\end{tabular}}} & \multirow{2}{*}{\multicolumn{2}{|c|}{\begin{tabular}{|c} 
Рак \\
тіла матки \\
жінки
\end{tabular}}} \\
\hline & \multicolumn{2}{|c|}{ чоловіки } & \multicolumn{2}{|c|}{ жінки } & \multicolumn{2}{|c|}{ жінки } & \multicolumn{2}{|c|}{ чоловіки } & & & & & & \\
\hline & 2000 & 2018 & 2000 & 2018 & 2000 & 2018 & 2000 & 2018 & 2000 & 2018 & 2000 & 2018 & 2000 & 2018 \\
\hline $\begin{array}{l}\text { Переважно високо- } \\
\text { індустріалізовані }\end{array}$ & 1.8 & 3.2 & 4.9 & 11.1 & 57.7 & 69.3 & 0.63 & 1.15 & 24.1 & 59.7 & 15.6 & 15.6 & 22.5 & 29.9 \\
\hline $\begin{array}{l}\text { Переважно сільськогос- } \\
\text { подарської діяльності }\end{array}$ & 1.3 & 3.7 & 5.5 & 13.6 & 51.1 & 62.1 & 0.76 & 1.21 & 28.1 & 57.3 & 13.8 & 15.5 & 19.8 & 30.5 \\
\hline $\begin{array}{l}\text { Змішаного характеру } \\
\text { господарювання }\end{array}$ & 1.8 & 3.8 & 4.7 & 14.0 & 58.5 & 67.1 & 0.63 & 0.93 & 25.7 & 66.5 & 14.4 & 16.6 & 21.3 & 30.8 \\
\hline $\begin{array}{l}\text { Підвищеного } \\
\text { радіаційного контролю }\end{array}$ & 2.2 & 3.7 & 6.8 & 12.6 & 45.0 & 60.9 & 0.48 & 0.75 & 25.3 & 49.2 & 14.9 & 16.4 & 19.1 & 29.4 \\
\hline Ендемічні за вмістом йоду & & 2.1 & 4.0 & 6.5 & 44.4 & 51.6 & 0.73 & 0.83 & 26.9 & 50.4 & 13.0 & 16.0 & 16.3 & 27.4 \\
\hline Середні по Україні & 1.8 & 3.8 & 6.3 & 13.0 & 53.9 & 65.9 & 0.7 & 1.0 & 27.6 & 56.8 & 14.8 & 15.8 & 20.6 & 30.0 \\
\hline
\end{tabular}


TO THE ISSUE OF THE PROBABLE ROLE OF PLANT PROTECTION CHEMICALS IN THE FORMATION OF POPULATION ONCOLOGICAL INCIDENCE

1Chernychenko I.O., ' Lytvychenko O.M., 1 Babii V.F., ${ }^{3}$ Fedorenko Z.P.,

${ }^{2}$ Tsymbaliuk S.M., 1 Balenko N.V., 1 Kondratenko O.Ye., 1 Hlavachek D.O. 1SI «O.M. Marzieiev Institute for Public Health, NAMS of Ukraine", Kyiv, Ukraine

${ }^{2}$ Kyiv City Clinical Endocrinology Center of MHU, Kyiv, Ukraine

${ }^{3}$ National Cancer Institute of MHU, Kyiv, Ukraine

Objective: We assessed a probable role of pesticides as generalized products of plant protection means in the formation of the hormonedependent oncological incidence in the population.

Materials and methods: In the work we analyzed the territorial features of plant protection chemicals use and the population endocrine cancer incidence data (breast and thyroid cancer in men and women, prostate cancer in men, ovarian and uterine cancer in women, calculated according to the Ukrainian standard) based on the materials from National Cancer Registry of Ukraine.

Results: Territorial dependences between gross indicators of the used chemical protection means, rates of their increase in the agriculture and indicators of the population endocrine cancer incidence were revealed. The most intensive growth was shown to be observed in the regions with a predominantly agricultural mode of production. The performed linear regression analysis confirmed a direct strong correlation between the volume of pesticide at the household use and the incidence of ovarian cancer $(r=0.89 ; p>0.01)$ and prostate cancer $(r=0.87 ; p>0.01)$.

Conclusion: Although the results of the analytical consideration of the problem and the data of linear-regression analysis indicate a possible role of pesticides in the induction of endocrine cancer, further research is needed in this field. In the future, it is important to consider the problem by classes and groups of pesticides with the possibility of the approach to the definition of the effect mechanisms.

\section{Keywords: plant protection chemicals, oncological incidence of the population, territorial features.}

Схиляючись до думки, що ХЗЗР таки впливають на стан формування онкологічної захворюваності, ми провели лінійний регресійний аналіз цих даних з залежною (захворюваність на гормонозалежні форми раку) і незалежною змінною (обсяги застосування ХЗЗР) з розрахунком коефіцієнтів кореляції (r) та коефіцієнтів регресії [16-18].

На рисунку представлено результати лінійного регресійного аналізу даних на прикладі захворюваності жінок на рак яєчників та чоловіків на рак передміхурової залози, які проживають у сільськогосподарських областях держави. Слід зазначити, що подібні зв'язки з різним ступенем достовірності виявлено і для інших нозологічних форм раку у групах областей промислового та змішаного типів господарювання.

Отримані дані вказують, що обсяги застосування пестицидів мають певний вплив на зростання рівнів захворюваності на досліджувану онкопатологію. Однак при цьому ми враховуємо, що, поперше, аналіз взаємозв'язку цих показників проводився на дещо обмеженій базі даних щодо обсягів застосування ХЗЗР в областях України, по-друге, аналіз проводився для пестицидів загалом, тоді як аналіз за окремими групами (гербіциди, інсектициди, фунгіциди), які відрізняються за своєю токсичністю і обсягами застосування, міг би бути більш інформативним.

Отримані дані можуть стати основою для подальшого розвитку досліджень впливу цього класу речовин на онкологічну захворюваність населення.

Таким чином, представлені матеріали свідчать про вплив ХЗЗР на захворюваність населення на гормонозалежні форми раку. Застосування при цьому регресійного аналізу з визначенням коефіцієнта регресії, який дає уявлення про те, як може змінюватися показник захворюваності через визначений (за допомогою кореляційного аналізу) термін прояву його впливу за зміни обсягів використання ХЗЗР, розширює можливості для довгострокового прогнозування онкологічної ситуації.

\section{Висновок}

Результати лінійно-регресійного аналізу показують, що пестициди можуть бути ймовірною причиною зростання гормонозалежної онкологічної патології у деяких областях України, однак необхідні подальші дослідження, щоб зрозуміти, як пестициди можуть викликати або сприяти змінам у розвитку, диференціюванні та/або злоякісній трансформації органів гормональної системи організму людини.

Зважаючи на значний вплив факторів довкілля на формування онкологічної патології, можна передбачити, що мінімізація хімічного впливу на людину сприятиме зменшенню ризику розвитку ракових захворювань та зміцненню громадського здоров'я.

ЛІТЕРАТУРА

1. Національний огляд «Ендокринні руйнівники в Україні: стан проблеми та шляхи її вирішення» / за ред. А.М. Сердюка, Д.А. Базики, М.Д. Тронька. Київ :

Медінформ, 2018. 156 с.

2. State of the Science of Endocrine Disrupting Chemicals / ed. by

\section{BNuाrovment \& Ileari! № 32021}


E.A. Bergman, J.J. Heindel, S. Joblingetal. Geneva : WHO, UNEP, 2012. $261 \mathrm{p}$.

3. Антомонов М.Ю.

Математическая обработка и анализ медико-биологических данных. 2-е изд. К. : Мединформ, 2018. 579 с.

4. Перелік пестицидів і агрохімікатів, дозволених до використання в Україні : Офіційне видання. Київ : Юнівест Медіа, 2016. 1023 с.

5. Пестициди. URL: https://uk.wikipedia.org/wiki/ח естициди

6.Пестициди : Довідник / за ред. С.Т. Омельчука. К. : Інтерсервіс, 2019. 904 с.

7. Пельо І.М. Застосування хімічних засобів у сучасних інтегрованих системах захисту овочевих культур як медико-екологічна проблема. Український журнал 3 проблем медицини праці. 2015. № 1. С. 67-76.

8. Balabanic D., Klemencic A.K. Endocrine-disrupting chemicals and male reproduc- tive health: a review. Zdrav. Vestn. 2018. Vol. 87, № 1-2. P. 60-80.

9. Weichenthal S., Moase C., Chan P. A review of pesticide exposure and cancer incidence in the agriculural health study cohort . Environ. Health Perspect. 2010. Vol. 118, № 8. P. 1117-1125.

10. Pluth T., Zanini L., Battisti I. Pesticide exposure and cancer: an integrative literature review. Saude em debate. 2019. Vol. 43, № 122. P. 906-924.

11. Antonenko A.M., Vavrinevych O.P., Korshun M.M., Omelchuk S.T. Hygienic assessment of the effects of pesticides application on adult population morbidity with thyroid gland diseases.

Wiadomo ci Lekarskie. 2018.

Vol. LXXI, № 2. P. 353-357.

12. Lemarchand C., Tual S., Levkque-Morlais N. et al. Cancer incidence in the AGRICAN cohort study (20052011). Cancer Epidemiol. 2017. Vol. 49. P. 175-185.

\section{Лінійно-регресійний аналіз зв'язку між обсягами застосування пестицидів та захворюваністю $\square$ жінок на рак яєчників $(r=0,89 ; p<0,01$; $y=10,8+0,003 x)$ \\ ч чоловіків на рак передміхурової залози $(r=0,87 ; p<0,001 ; y=24,5+0,013 x)$.}
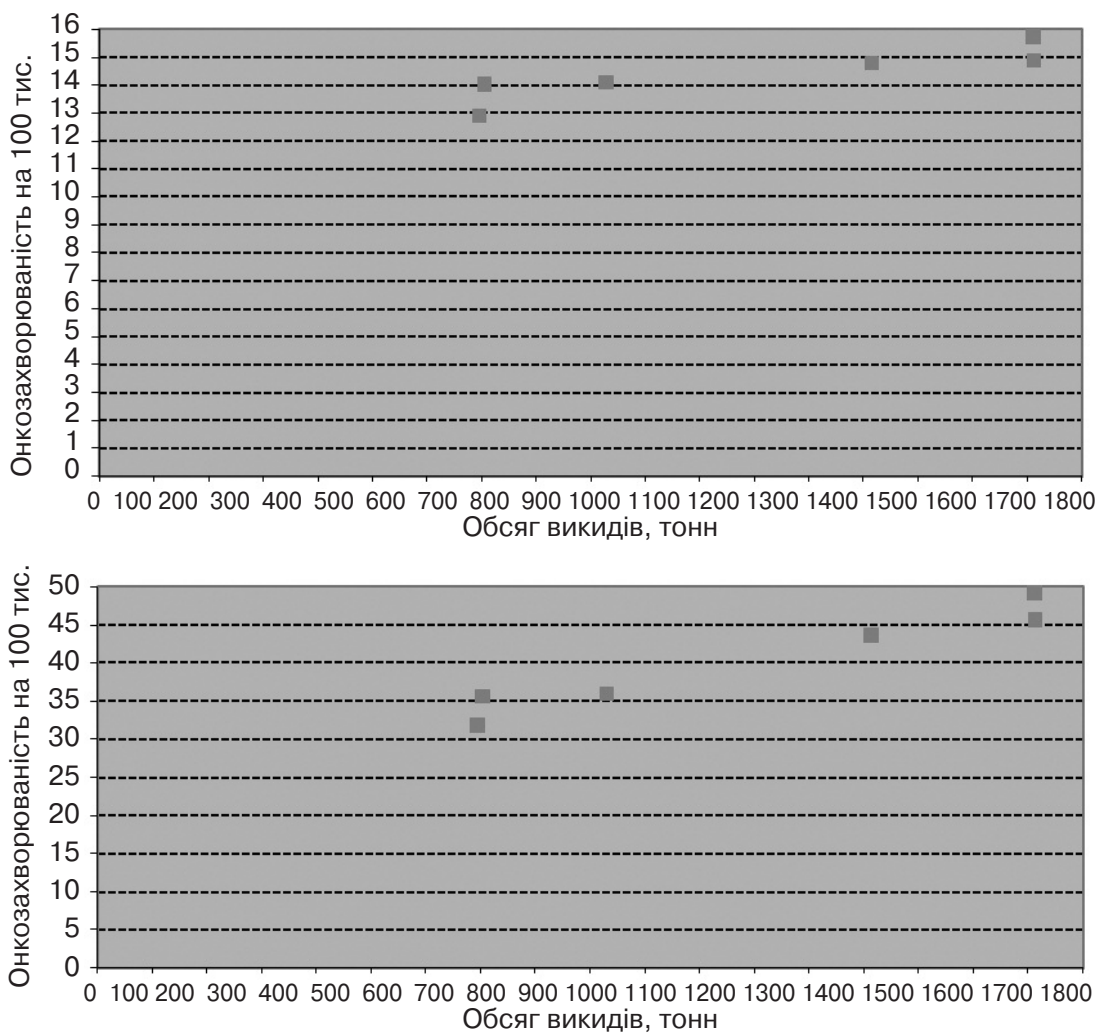

13. Salerno C., Carcagnm A., Sacco S. et al. An Italian population-based case-control study on the association between farming and cancer: Are pesticides a plausible risk factor? Archives of

Environmental \& Occupational Health. 2016. Vol. 71, Issue 3. P. 147-156.

14. Kass L., Gomez A., Altamirano G. Relationship between agrochemical compounds and mammary gland development and breast cancer. Molecular and Cellular Endocrinology. 2020. Vol. 508. P. 10779-10783.

15. Lee E., Kinninger F., Giske Ursin G. et al. Serum Levels of Commonly Detected Persistent Organic Pollutants and Per- and Polyfluoroalkyl Substances (PFASs) and Mammographic Density in Postmenopausal Women. Int J. Environ Res Public Health. 2020. Vol. 17, № 2. P. 606-610.

16. Vu V., Navalkar N., Wei Yu. Endocrine-disrupting metals in ambient air and female breast cancer incidence in US. Gynecological Endocrinology. 2019. Vol. 35. P. 1099-1102.

REFERENCES

1. Serdiuk A.M., Bazyka D.A., Tronka M.D. Natsionalnyi ohliad «Endokrynni ruinivnyky v Ukraini: stan problemy ta shliakhy yii vyrishennia» [National Review «Endocrine Disruptors in Ukraine: The State of the Problem and Ways to Solve It»]. Kyiv: Medinform; 2018: 156 p. (in Ukrainian).

2.Bergman E.A., Heindel J.J., Joblingetal S. (Eds.). State of the Science of Endocrine Disrupting Chemicals.Geneva : WHO, UNEP; 2012 : 261 p.

3. Antomonov M.Yu. Matematicheskaya obrabotka i analiz mediko-biologicheskih dannyh. Vtoroe izdanie [Mathematical Processing and Analysis of Biomedical Data. Second edition]. Kyiv: Medinform; 2018: 579 p. (in Russian).

4. Perelik pestytsydiv i ahrokhimikativ, dozvolenykh do vykorystannia v Ukraini: 
К ВОПРОСУ О ВЕРОЯТНОЙ РОЛИ

ХИМИЧЕСКИХ СРЕДСТВ ЗАЩИТЫ РАСТЕНИЙ

В ФОРМИРОВАНИИ ОНКОЛОГИЧЕСКОЙ

ЗАБОЛЕВАЕМОСТИ НАСЕЛЕНИЯ

1 Черниченко И.А., 1Литвиченко О.Н.,

1Бабий В.Ф., ЗФедоренко З.П.,

2Цимбалюк С.Н., 1Баленко Н.В.

1 Кондратенко О.Е., 1 Главачек Д.А.

1 ДУ «Институт общественного здоровья им. А.Н. Марзеева НАМН Украины», Г. Киев,

Украина

2Киевский городской эндокринологический

центр МЗ Украины, г. Киев, Украина

зНациональный институт рака МЗ Украины,

г. Киев, Украина

Цель: оценить вероятную роль пестицидов как обобщающих продуктов химических средств защиты растений в формировании гормонозависимой онкологической заболеваемости населения.

Материалы и методы. В работе проанализированы территориальные особенности использования химических средств защиты растений и данные заболеваемости населения раком эндокринных органов (рак молочной и щитовидной желез у мужчин и женщин, рак простаты у мужчин, рак яичников и тела матки у женщин, рассчитанных по украинскому стандарту) по материалам Национального канцер-реестра Украины.
Результаты. Выявлена территориальная зависимость между валовыми показателями используемых химических средств защиты, темпами их увеличения в сельском хозяйстве и показателями заболеваемости населения раком эндокринных органов.

Показано, что наиболее интенсивно растут показатели в областях с преимущественно сельскохозяйственным производством. Проведенный линейно-регрессивный анализ подтвердил наличие прямой сильной корреляционной связи между объемами применения в хозяйстве пестицидов и заболеваемостью раком яичников у женщин $(r=0,89$; $p>0,01)$ и раком простаты у мужчин $(r=0,87$; $p>0,01)$.

Вывод: хотя результаты аналитического рассмотрения проблемы и данные линейнорегрессивного анализа указывают на возможную роль пестицидов в индуцировании рака эндокринных органов, необходимо продолжение исследований в этой области. Важно в дальнейшем рассмотреть проблему по классам и группам пестицидов с возможностью подхода к определению механизмов действия.

\section{Ключевые слова: химические средства защиты растений,онкологическая заболеваемость населения, территориальные особенности.}

Ofitsiine vydannia [List of Pesticides and Agrochemicals Approved for Use in Ukraine: Official Publication]. Kyiv: Yunivest Media; 2016: 1023 p. (in Ukrainian).

5. Pestytsydy [Pesticides]. URL: https://uk. wikipedia.org/ wiki/ Pestytsydy

(in Ukrainian).

6. Omelchuk S.T.Pestytsydy: Dovidnyk [Pesticides :

Directory]. Kyiv : Interservis; 2019: 904 p. (in Ukrainian).

7. Pelo I.M. Zastosuvannia khimichnykh zasobiv u suchasnykh intehrovanykh systemakh zakhystu ovochevykh kultur yak medyko-ekolohichna problema [The Using of Chemicals in Modern Integrated Systems for the Protection of Vegetable Crops as a Medical and Environmental Problem]. Ukrainian Journal of Occupational Health. 2015; 1 : 67-76 (in Ukrainian).

8. Balabanic D. and Klemencic A.K. EndocrineDisrupting Chemicals and Male Reproductive Health: A Review. Zdrav. Vestn. 2018 ; 87 (1-2) : 60-80.
9. Weichenthal S., Moase C. and Chan P. A Review of Pesticide Exposure and Cancer Incidence in the Agriculural Health Study Cohort. Environ. Health Perspect. 2010 ; 118 (8) : 1117-1125.

10. Pluth T., Zanini L. and Battisti I. Pesticide Exposure and Cancer: an Integrative Literature Review. Saude em debate. 2019 ; 43 (122) : 906-924.

11. Antonenko A.M., Vavrinevych O.P., Korshun M.M. and Omelchuk S.T. Hygienic Assessment of the Effects of Pesticides Application on Adult Population Morbidity with Thyroid Gland Diseases. Wiadomo ci Lekarskie. 2018 ; LXXI (2) : 353-357.

12. Lemarchand C., Tual S., Levkque-Morlais N. et al.

Cancer Incidence in the AGRI-

CAN Cohort Study (2005-

2011). Cancer Epidemiol. 2017 ; 49 : 175-185.

13. Salerno C., Carcagnm A., Sacco S. et al. An Italian Population-Based CaseControl Study on the
Association Between Farming and Cancer: Are Pesticides a Plausible Risk Factor?Archives of Environmental \& Occupational Health. 2016 ; 71 (3) : 147-156.

14. Kass L., Gomez A. and Altamirano G. Relationship between Agrochemical Compounds and Mammary Gland Development and Breast Cancer. Molecular and Cellular Endocrinology. 2020 ; 508 : 10779-10783.

15. Lee E., Kinninger F., Giske Ursin G. et al. Serum Levels of Commonly Detected Persistent Organic Pollutants and Per- and Polyfluoroalkyl Substances (PFASs) and Mammographic Density in Postmenopausal Women. nt J. Environ Res Public Health. 2020 ; 17 (2) : 606-610.

16. Vu V., Navalkar N. and Wei Yu. Endocrine-Disrupting Metals in Ambient Air and Female Breast Cancer Incidence in US. Gynecological Endocrinology. 2019 ; 35 : 1099-1102.

Надійшло до редакції 28.05.2021

\section{Bnvirovinest \& Ileari! № 32021}

